\title{
USE OF EDMODO IN IMPROVING SELF-EFFICACY
}

\author{
Andy Sapta ${ }^{1} \&$ Cecep Maulana ${ }^{2}$ \\ ${ }^{1,2}$ Management and Computer Informatics School of Royal, Kisaran \\ e-mail: sapta@royal.ac.id
}

\begin{abstract}
Utilizing virtual learning environments as a supplementary tool for motivating and empowering independent learning and innovative teaching is becoming a crucial part of a 21 st century education. Edmodo is one example of social learning site which is now being used by professors and students in many institutions of higher learning. The purpose of this research is to know the use of edmodo in improving student self-efficacy in learning.This research focuses on the effectiveness from students' perspective of the use of Edmodo as a complementary tool in improving student self-efficacy. The population of this study is the initial semester students STMIK Royal Kisaran which amounted to 354 people. The sample was obtained by using cluster random sampling method. The Psychological Approaches target the "software," learned faulty behaviors and habits, along with damaging words, thoughts, interpretations, and feedback that direct strategies for daily living. In this research, 35 students voluntarily participated in the focus group discussions and interviews dealing with their experiences using Edmodo. Overall, the findings affirmed that majority of participants considered Edmodo as an effective supplementary tool for their learning. With the increase in student motivation can improve student self-efficacy in learning, so that the learning plan that has been designed in well achieved.
\end{abstract}

Keywords: edmodo, self-efficacy

\section{INTRODUCTION}

The use of technology as media in teaching learning process has spread.The media which is considered as the appropriate media is based on internet used. It is caused internet offers many kinds of application, online media and software which support teaching learning process. Based on this assumption, the teachers should implement electronic learning tools to develop their teaching.

Rahmawati (2015) stated that there are some choices to implement e-learning as a media in the teaching learning process, they are (1) developing e-learning by ourselves, (2) buying a system, (3) using open source e-learning. Open source e-learning is software free to use, and the original program can be changed by anyone. There are lots of free and open source E-Learning applications that can be used by both teachers and students, such as: eduslide, yacapaca, moodle, quipper school, edmodo etc.

Edmodo is a closed social learning network which is considered unique compared to other Social Networking Sites (SNSs) such as Facebook and Twitter because it gives a safe, private setting to users. Each student has a private access code provided by the teacher and this private code enables her/him to join Edmodo. Hence, no strangers can join it. Besides, there is no personal information required from the students to join, so it is completely secure.

STMIK Royal Kisaran now perceive edmodo as an educational trend for the future. Edmodo is cost effective and can reach more learners. In some sense, it is seen as more creative ways in teaching as well as a sustainable way for learning. Though many studies report success stories of online learning in terms of retention and effectiveness. And findings still show edmodolearners have difficulties in dealing with their learning environment (Cavanaugh, 2005; Cook \& Jenkins, 2010; Levy, 2007). Despite using computers and technology in their daily life, they might feel less confident about enrolling in online classes, especially at the tertiary level. They might not have enough of the 
necessary learning and technology skills for the combination of STMIK Royal Kisaran and edmodo learning such as skills to compose essays, prepare presentations, analyse data, and do research work.

Many students still find it hard to adapt and perform well in STMIK Royal Kisaran online classes because of the demands and stress of the transition from senior hight school or vacationalhight school to university especially at first semester. Some students struggle to cope with the complexity of an onlineenvironment and often have doubts about their learning performance. On the other hand,these students will put forth a high degree of effort in order to meet their commitments, and attribute failure to things which are in their control, rather than blaming external factors. Selfefficacious students also recover quickly from setbacks, and ultimately are likely to achieve their personal goals. Students with low self-efficacy, on the other hand, believe they cannot be successful and thus are less likely to make a concerted, extended effort and may consider challenging tasks as threats that are to be avoided. Thus, students with poor self-efficacy have low aspirations which may result in disappointing academic performances becoming part of a self-fulfilling feedback cycle, and many public school institutions are migrating toward the adoption of an online learning environment to replace or supplement the traditional pedagogical format. For a new system to be adopted and implemented effectively or a previously implemented system to run successfully, a solid understanding of user acceptance must occur because a teacher' s behavioral intention and attitude toward the system play an important role in the adoption of the system.

\section{METHODOLOGY}

This type of research is quasi experiment. The group used in this study consisted of two groups. One group uses a conventional learning method that is teacher center, and one group uses edmodo in learning. The research was conducted at STMIK Royal Kisaran, North Sumatra. The population of this study is the students of Information System courses in the odd semester of the academic year 2016/2017. The study population is 512 students divided into 13 classes. The sample of this research was obtained by using cluster random sampling technique. The study sample consisted of six classes divided into two groups. Each group consists of three classes. The experimental group used edmodo in the learning process, and the control group applied conventional learning which was more directed to the teacher center method.

This research data is quantitative data in the form of student self-efficacy data. In the experimental group the research data was obtained from the question and answer at the beginning of the learning. For the research data in the control group obtained from the test of learning outcomes conducted at the end of learning

\section{RESULTS AND DICCUSION}

This study in progress centres the attention on the link between learner control, self-efficacy, and other factors such as previous experience in online learning programme and computer skills. In addition, literature in this area shows a few studies that have investigated experiencing levels of learner control in a real online class setting (Jaffe, 1997). Most learner control research has compared outcomes between learner control embedded in web-based learning and those in traditional learning environments (e.g.,Chang \& Ho, 2009; Chou \& Liu, 2005). Therefore, this study focuses on learners in the formal setting of online learning programmes designed to encourage learner control in higher educational institutions.

Building on previous research this study uses a quantitative approach framed by Bandura' $\mathrm{s}$ self-efficacy theory (1977). The population frame is online learners in an online programme at STMIK Royal Kisaran.The purposive sample group is learners in an online programme where levels of learner control were embedded within the course design which learners are encouraged to do a group project in their own ways or they are allowed to complete different tasks choosing their own order within a flexible time frame. To measure learners' perceived confidence toward their online learning programme, the self-efficacy scales are constructed, piloted and validated. Hypothetically, if the correlation between learner control and learners' self -efficacy does exist, learners who are studying in high learner-controlled online programme should have high self-efficacy toward their learning environment. 
The questionnaire was constructed by items generated from the reviewed literature and previous validated tools. After reviewed by scholars and experts in the fields, the initial questionnaire comprised four sections: (1) demographic data, (2) a self-report of learners' computer skills, previous online learning experience, and experience with learner control, (3) an online learning self-efficacy scale (OLSE), and (4) open-ended questions for qualitative data.Then, a pilot study was conducted to test validity of the research instrument and to establish preliminary findings. Thirty-five students, 13 males and 22 females, participated in this online survey. About 75\% of participants were 19 to 22 years old. About $80 \%$ had some to a lot of online learning experience. Seventy-five percent reported themselves having intermediate computer skills, and the rest were advanced users.

The preliminary findings showed a positive relationship between learner control and online self-efficacy. Pearson' s product-moment correlation coefficient was calculated $r(32)=0.393$ at a significant level of 0.05 . This coefficient meant that students' self-efficacy increased along with the level of learner control they had experience. The more in-depth study is planned for a larger and more diverse sample group in term of learner control after the questionnaire was adjusted and validated. Qualitative data, then, is analyses and used to triangulate the quantitative findings. It is hoped that the results of this study may prove useful for educators and developers in shedding some light on how to make future online students more comfortable and confident in unfamiliar and complex online environments. Novice and inexperienced online students who possess low confidence in their ability might find it easier to interact, collaborate, and thus succeed in online courses when learner control is integrated into the edmodo environment from the beginning as part of the course design.

\section{CONCLUSION}

Use of edmodo applications in learning can improve student self-efficacy. The use of edmodo makes students more comfortable and improves students' self-confidence. This is stated from the results of research that has been carried out on early semester students in SMTIK Royal Kisaran. With the increase of self-efficacy will certainly have a positive effect on improving student learning outcomes.

\section{REFERENCES}

Arroyo, G. (2011). On-Line Social Networks: Innovative Ways towards the Boost of Collaborative Language Learning. ICT for Language Learning (4th ed.). Retrieved Oct 7, 2013

Cavanaugh, J. (2005). Teaching Online - A Time Comparison. Online Journal of Distance Learning Administration

Chang, M., \& Ho, C. (2009). Effects of Llocus of Control And Learner-Control on Web-Based Language learning. Computer Assisted Language Learning. 22(3): 189-206.

Chou, S. W., \& Liu, C. H. (2005). Learning Effectiveness In A Web-Based Virtual Learning Environment: A Learner Control Perspective. Journal of Computer Assisted Learning. 21: 6576

Chowdhury, M. S., \& Shahabuddin, A. M. (2007). Self-Efficacy, Motivation And Their Relationship to Academic Performance of Bangladesh College Students. College Quarterly. 10(1): 1-9.

Jaffe, J. M. (1997). Media Interactivity And Self-Efficacy: an Examination of Hypermedia First Aid Instruction.

Luskin, B., \& Hirsen, J. (2010). Media Psychology Controls The Mouse That Roars. In K. E. Rudestam \& J. Schoenholtz-Read (Eds.), Handbook of Online Learning. Thousand Oaks, CA: SAGE Publications, Inc.

Piccoli, G., Ahmad, R., \& Ives, B. (2001). Web-Based Virtual Learning Environments: A Research Framwork

Rahmawati, R. dkk. (2015), The Effectiveness of E-Learning - Quipper School Application on The Accounting Learning At State Senior Secondary School 2 of Surakarta. Surakarta. FKIP Universitas Sebelas Maret

Roffe, L. (2002). E-learning: Engagement, Enhancement And Execution, Quality Assurance in, 10(1): 40-50. 
Saadé, R. G., \& Kira, D. (2009). Computer Anxiety In E-Learning: The Effect of Computer SelfEfficacy. Journal of Information Technology Education, 8: 177-191.

Sapta, Andy. "Publication of The Assessment Learning Outcomes Through Social Media." In The 1st Annual International Seminar on Transformative Education and Educational Learship, pp. 480-483. 2016.

Vancouver, J. B., \& Kendall, L. N. (2006). When Self-Efficacy Negatively Relates to Motivation And Performancein A Learning Context. Journal of Applied Psychology, 91(5): 1146-1153 